\title{
Edukasi dan Pengelolaan Sampah Model Sentralisasi Kepada Masyarakat Dusun Dandangan Kecamatan Deket Kabupaten Lamongan Melalui Peran Serta Karang Taruna ARDAS (Arek Dandangan Asli)
}

\author{
Gagok Setiawan ${ }^{1}$, Taufik Rahman ${ }^{2}$ \\ ${ }^{1}$ Program Studi Teknik Industri, Fakultas Teknik dan Informatika, Universitas Gajayana - Merjosari Malang \\ E-mail: gagok.setiawan@unigamalang.ac.id. No. HP:+6281231822322 \\ ${ }^{2}$ Program Studi Teknik Informatika, STT STIKMA Internasional Malang - Merjosari Malang \\ E-mail: ktopik@gmail.com No. HP:+6281357901694
}

\begin{abstract}
ABSTRAK
Volume sampah di Indonesia semakin meningkat seiring dengan pertambahan jumlah penduduk. Tidak hanya di kota-kota besar metropolitan saja sampah menjadi sumber permasalahan, tetapi di daerah khususnya wilayah desa dan dusun, juga mempunyai masalah dengan meningkatnya jumlah sampah. Banyak cara telah dilakukan oleh masyarakat tetapi pengelolaan sampah yang benar belum sepenuhnya diterapkan. Di Dusun Dandangan Kabupaten Lamongan, pengelolaan sampah masih menggunakan cara-cara tradisional, yaitu ditimbun dengan tanah dengan asumsi akan lebur dengan tanah tapi melupakan polusi tanah yang juga mempengaruhi air tanah, adapula yang dibakar dengan tujuan agar semua berubah menjadi abu. Tetapi hal ini juga akan menimbulkan polusi udara. Oleh karena itu dengan kerjasama antara pemerintah daerah yaitu Kepala Dusun Dandangan dengan unit Karang Taruna ARDAS (Arek Dandangan Asli), berupaya mengelola sampah dengan model sentralisasi sebagai tahap awal kegiatan. Berdasarkan hasil kuesioner mengenai pengetahuan warga tentang bagaimana mengelola sampah, maka pada awalnya hampir 75\% warga tidak paham bagaimana dampak pengelolaan sampah yang salah. Setelah dilaksanakan penyuluhan, maka lebih dari $85 \%$ warga memahami bahwa begitu besar polusi yang timbul akibat pengelolaan sampah yang salah. Begitupula pada kuesioner kedua mengenai tingkat kepuasan warga dengan adanya program ini, maka sebanyak 95,77\% menyatakan sangat puas dengan kegiatan ini. Diharapkan program ini ditingkatkan ke tahap desentralisasi sehingga mampu mengurangi volume sampah di wilayah Dusun Dandangan Kabupaten Lamongan.
\end{abstract}

Kata kunci : sampah; sentralisasi; karang taruna; pengelolaan sampah; desentralisasi.

\section{ABSTRACT}

The volume of waste in Indonesia is increasing along with population growth. Not only in large metropolitan cities, garbage is the source of problems, but in areas especially villages and hamlets, it also has problems with the increasing amount of waste. Many ways have been done by the community, but proper waste management has not been fully implemented. In Dusun Dandangan, Kabupaten Lamongan, waste management still uses traditional methods, namely landfill with the assumption that it will melt with the soil but forget about soil pollution which also affects groundwater, there are also those that are burned with the aim that all turn into ash. But this will also cause air pollution. Therefore, cooperation between the regional government, it's Kepala Dusun Dandangan with the ARDAS (Arek Dandangan Asli) Youth Organization, trying to manage waste with a decentralization model as the initial stage of activity. Based on the results of the questionnaire regarding people's knowledge about how to manage waste, initially almost $75 \%$ of

Cara Mengutip : Setiawan, G., Rahman, T., (2019). Edukasi dan Pengelolaan Sampah Model Sentralisasi Kepada Masyarakat Dusun Dandangan Kecamatan Deket Kabupaten Lamongan Melalui Peran Serta Karang Taruna ARDAS (Arek Dandangan Asli). JAST : Jurnal Aplikasi Sains dan Teknologi, 3 (1), 24-33. http://dx.doi.org/10.33366/jast.v3i1.1272 
the residents did not understand how the effects of waste management were wrong. After counseling, more than $85 \%$ of residents understand that so much pollution arises due to improper waste management. Likewise in the second questionnaire regarding the level of citizen satisfaction with the existence of this program, as many as $95.77 \%$ stated that they were very satisfied with this activity. It is expected that this program will be upgraded to the decentralization stage so that it can reduce the volume of waste in the Dusun Dandangan area of Kabupaten Lamongan.

Keywords : waste; centralization; youth organization; waste management; decentralization.

\section{PENDAHULUAN}

Masalah pelik yang sering dihadapi Pemerintah Indonesia adalah sampah. Tidak hanya di Indonesia namun di negara-negara lain, bahkan negara maju, sampah juga seringkali menjadi topik diskusi untuk diselesaikan. Pengelolaan sampah paling mudah adalah dengan dikubur dalam tanah atau dibakar sampai habis. Namun seringkali hal ini menjadi permasalahan baru lagi karena efek dari aktivitas tersebut menghasilkan dampak ke lingkungan. Sampah yang tidak dapat teruraikan bila ditimbun dalam tanah akan menyebabkan polusi yang akan mengurangi tingkat kesuburan tanah sehingga tidak dapat ditanami dalam waktu lama. Bila dibakar akan menyebabkan polusi udara yang membahayakan. Maka perlu pemikiran lebih lanjut bagaimana mengelola sampah yang memikirkan dampaknya pada lingkungan. Berdasarkan artikel pada Kompas Muda [1] dikatakan bahwa ratarata sebanyak 7500 ton setiap harinya, sampah yang dihasilkan masyarakat di Jakarta. Dapat dibayangkan berapa juta ton sampah yang dihasilkan seluruh masyarakat di Indonesia. Pemerintah Indonesia sendiri telah mengamanatkan pengelolaan sampah dalam UndangUndang Nomor 18 Tahun 2008 [2] dimana pengelolaan sampah dimulai dari tingkat hulu yaitu produsen atau penghasil sampah, antara lain masyarakat, industri, pasar tradisional dan lain-lain. Sehingga sampah yang dihasilkan oleh produsen sampah telah dikelola sebelum menuju ke Tempat Pembuangan Akhir (TPA). Namun masyarakat sendiri belum terpola untuk mengelola sampahnya sendiri, baik sampah organik maupun non organik, seluruh sampah dijadikan satu langsung menuju ke TPA. Oleh karena itu model pengelolaan sampah di Indonesia masih menggunakan model sentralisasi dan desentralisasi yang tidak maksimal, bahkan dengan sistem open dumping [3] yang jelas-jelas dilarang oleh Pemerintah

Di wilayah Dusun Dandangan sendiri, jumlah Kepala Keluarga (KK) di Desa Dandangan adalah sebanyak 300 KK, sistem pengelolaan sampahnya tidak ada. Masyarakat membuat lubang sendiri di belakang rumah dengan asumsi bahwa sampah ini nantinya akan dikubur dalam tanah kemudian terurai atau akan dibakar sehingga habis tinggal abu dan sekamnya. Bila semua rumah membuat pola pembuangan seperti ini, dapat dibayangkan betapa kotornya wilayah Dusun Dandangan dan akan tercium bau busuk dari masing-masing rumah akibat proses pembusukan yang terjadi. Lebih parahnya lagi bila terlalu banyak sampah yang dihasilkan oleh satu rumah saja, maka dibuang ke sungai dengan pola pikir praktis dimakan ikan di sungai. Padahal 
sampah plastik tidak akan terurai walau di air, dan menyebabkan polusi air bahkan banjir. Untuk itu perlu adanya edukasi ke masyarakat Dusun Dandangan tentang bagaimana mengelola sampah yang benar dan mengikutsertakan seluruh pihak terkait dalam hal ini mulai dari perangkat desa sampai dengan unit-unit pendukung, salah satunya adalah Anggota Karang Taruna ARDAS (Arek Dandangan Asli) Dusun Dandangan Kabupaten Lamongan. Keikutsertaan Karang Taruna ARDAS sangat penting agar generasi muda ikut berpartisipasi dan memikirkan bagaimaa pengelolaan sampah di lingkungannya dan nantinya menurunkan kebiasaan baik ini ke keluarganya maupun keturunannya.

Selama ini belum ada upaya nyata baik dari Pemerintah Kabupaten Lamongan maupun dari masyarakat Desa Dandangan setempat tentang bagaimana mengelola sampah dengan benar. Sehingga penulis berupaya memberikan penyuluhan serta edukasi yang dimulai dari Anggota Karang Taruna ARDAS sebagai pioneer kegiatan.

\section{METODE KEGIATAN}

Dalam menjalin komunikasi dengan Pemerintah Daerah yang berwenang yaitu Kepala Dusun Dandangan Kabupaten Lamongan, penulis menyampaikan proposal kegiatan yang terperinci agar dapat dimengerti serta mudah berkoordinasi sehingga kegiatan dapat dijalankan. Mengingat setiap langkah yang diambil, harus diketahui dan disahkan oleh Kepala Dusun sehingga lancar dan berhasil sampai proses akhir. Beberapa metode yang akan dilakukan oleh penulis adalah sebagai berikut :

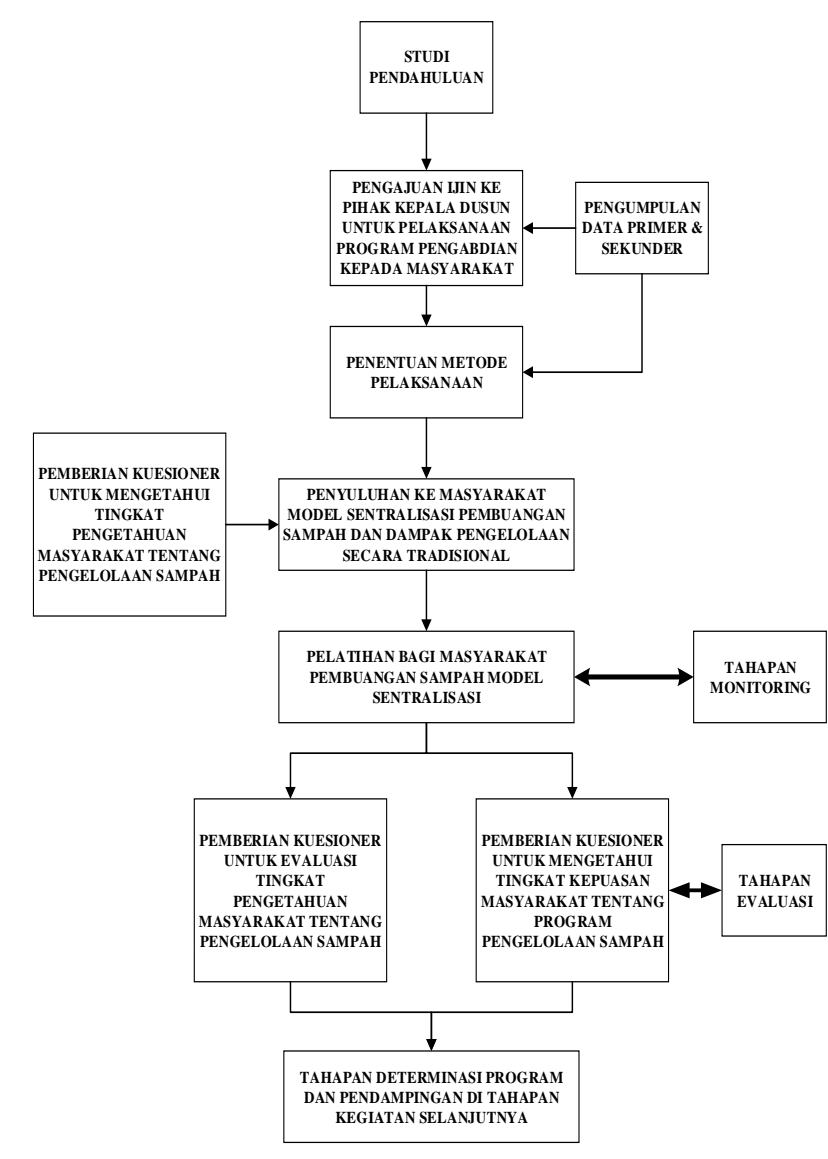

Gambar 1. Tahapan Pelaksanaan Kegiatan

- Penyuluhan Masyarakat

Sebagai metode awal adalah melakukan penyuluhan ke masyarakat Dusun Dandangan Kabupaten Lamongan bagaimana cara mengelola sampah tanpa harus dibuang di belakang rumah masing-masing.

\section{- Pelatihan}

Menindaklanjuti kegiatan penyuluhan ke masyarakat, diikuti dengan kegiatan pelatihan. Pelatihan yang diberikan antara lain : a) membiasakan untuk mulai membungkus sampah di kantong plastik (lebih baik lagi dengan kantong plastik khusus sampah) agar memudahkan mengambil dari rumah masing-masing warga (tidak tercecer); b) petugas yang rencananya mengambil sampah adalah anggota Karang Taruna 
ARDAS yang bergiliran sesuai jadwal, sehingga mulai belajar mengoperasikan kendaraan pengangkut sampah jenis Nozomi $200 \mathrm{cc}$.

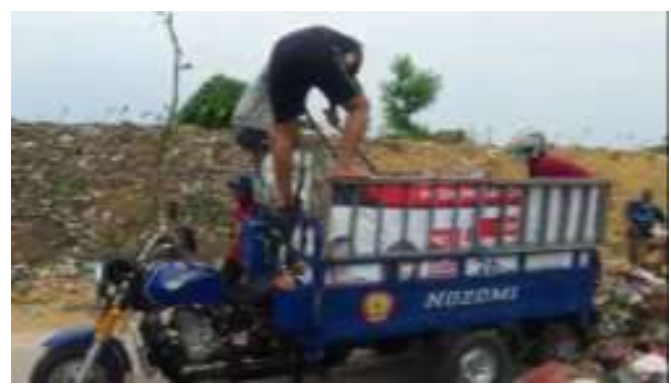

Gambar 1. Jenis Kendaraan Pengangkut Sampah

Pengoperasian kendaraan jenis ini berbeda dengan jenis mobil pick-up atau sepeda motor biasa sehingga harus dibiasakan cara mengoperasikannya; c) mulai dilatih membedakan sampah jenis organik dan sampah non organik karena rencana ke depannya sampah akan didaur ulang menjadi produk baru.

Diharapkan melalui kedua metode ini mampu mengubah cara pengelolaan sampah masyarakat Dusun Dandangan sehingga tercapai lingkungan yang bersih dan sehat.

\section{KARYA UTAMA}

Pada program pengelolaan sampah ini, ada dua kegiatan seperti yang telah disebutkan pada subbab Metode Kegiatan, yang menjadi fokus utama untuk diterapkan kepada masyarakat Dusun Dandangan. Kegiatan tersebut adalah penyuluhan masyarakat dan pelatihan penerapan model pengelolaan sampah.

\subsection{Penyuluhan Masyarakat}

Penyuluhan ini dilaksanakan selama 1 bulan yaitu bulan Januari 2019 dengan pendekatan ke pihak Pemerintah Daerah setempat, yaitu Kepala Dusun Dandangan
Kabupaten Lamongan selama dua bulan yaitu November sampai dengan Desember 2018. Dari metode penyuluhan ini dilakukan pencarian data, baik yang berupa kuesioner yang dibagikan sebelum dan setelah masyarakat memperoleh penyuluhan maupun data demografi penduduk Dusun Dandangan Kabupaten Lamongan untuk dapat memperkirakan berapa kilogram sampah yang dihasilkan per harinya sehingga dapat menjadwal pengambilan sampah untuk dibuang di Tempat Pembuangan Akhir (TPA). Dengan jadwal yang teratur dalam seminggu, masyarakat akan mulai menata pola pengelolaan sampahnya sehingga bila ada kegiatan khusus, misalnya acara selamatan dan lain-lain maka masyarakat akan berpikir bagaimana menata sampahnya, bagaimana membuangnya, apakah diserahkan ke petugas yang mengambil sampah sesuai jadwal atau memberikan biaya tips tambahan ke petugas. Sehingga kedisiplinan dalam mengelola sampah akan tetap terjaga. Pengelolaan sampah terbagi menjadi 3 model [4] yaitu :

1. Pengelolaan sampah model sentralisasi, dimana bermuara langsung pada TPA;

2. Pengelolaan sampah model desentralisasi, dimana pengelolaan sampah dilakukan oleh produsen sampah, yaitu masyarakat sendiri dengan memilah sampahnya menjadi organik dan anorganik;

3. Pengelolaan sampah model Sentralisasi - Desentralisasi (Se-Desentralisasi), dimana masyarakat dengan dibimbing Pemerintah menyusun beberapa tahapan pengelolaan sampai menjadi industri pengelolaan sampah di tahap akhir. 
Pengelolaan sampah di Dusun Dandangan ini mengambil model sentralisasi sebagai langkah awal mengelola sampahnya. Karena bentuk ini paling mudah disosialisasikan terlebih dahulu sebelum masyarakat diajak untuk mulai memilah sampahnya dan mendaur ulang.

\subsection{Pelatihan Masyarakat}

Pelatihan pertama adalah membentuk pola pikir masyarakat dengan membungkus terlebih dahulu sampah sebelum dibuang di tempat sampah. Jadwal yang direncanakan untuk pengambilan sampah adalah pada hari Senin, Kamis dan Sabtu. Hal ini dimaksudkan agar pada saat warga membuang sampah tidak pada ketiga hari tersebut maka sampah tidak akan berceceran di tempat sampah yang akan mengundang lalat dan bakteri penyebab penyakit. Selain itu pemandangan rumah akan terlihat lebih rapi dan bersih bila tempat sampah di depan rumah hanya terlihat bungkusan sampah tanpa ada ceceran sampah menggunung yang belum diambil. Pelatihan selanjutnya adalah membentuk satuan tugas yang akan mengambil sampah pada hari-hari yang telah ditetapkan. Berikut struktur organisasi yang mengurus pengelolaan sampah di Dusun Dandangan Kabupaten Lamongan.

Adapun jumlah anggota Karang Taruna ARDAS adalah sebanyak 50 orang, tetapi tidak semuanya menjadi petugas karena masih banyak yang sekolah. Sehingga jumlah petugas yang mengambil sampah adalah sebanyak 2 orang, sedangan 6 orang adalah sebagai pengurus dan administrasi. Pembagian kerja disesuaikan dengan waktu yang dimiliki para anggota, kadangkala bila tanggal merah maka anggota lain ikut berpartisipasi dalam pengelolaan sampah yang ada. Selain itu dilatih pula bagaimana mengoperasikan kendaraan tipe Nozomi 200 cc ke petugas yang mengangkut sampah serta 1 orang adalah bagian mekanik. Saat ini dari pengurus yang ada mampu menangani $300 \mathrm{KK}$ yang ada di Dusun Dandangan Kabupaten Lamongan. Setelah sampah diambil dan dikumpulkan maka rencana selanjutnya akan dibuang ke TPA di wilayah Kabupaten Lamongan.

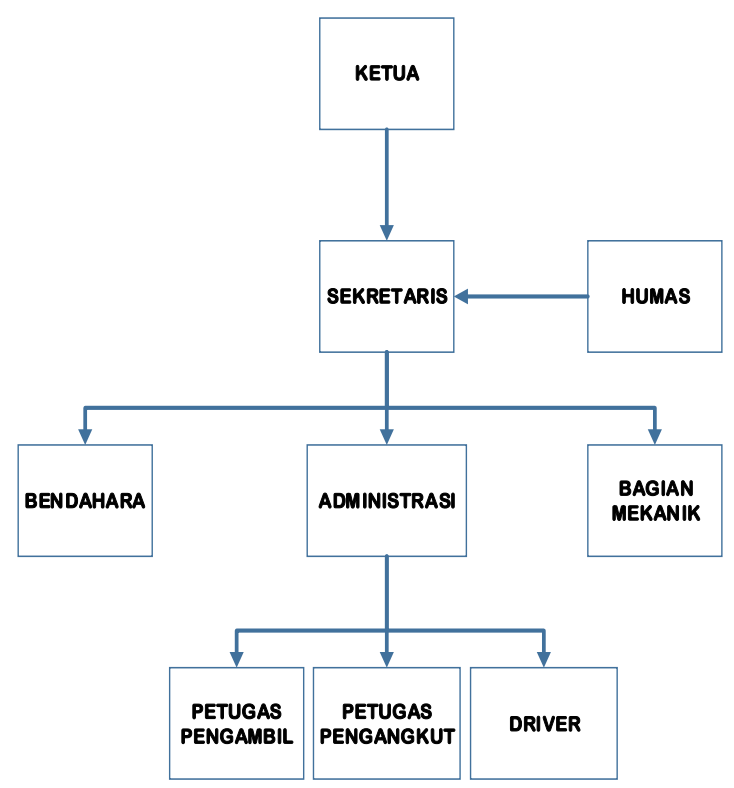

Gambar 2. Struktur Organisasi Pengelola Sampah Dusun Dandangan Kabupaten Lamongan

Model Sentralisasi pengelolaan sampah yang diambil penulis sebagai awal kegiatan menjadi kemufakatan dengan pemerintah daerah yang mana adalah Kepala Dusun Dandangan Kabupaten Lamongan. Petugas mengambil sampah dari masing-masing rumah pada hari yang telah ditetapkan dan sampah sudah terbungkus rapi dalam kantong plastik 
sehingga tidak akan tercecer saat akan dibawa ke TPA. Untuk TPA yang menjadi tujuan adalah TPA Tambakrigadung Kabupaten Lamongan.

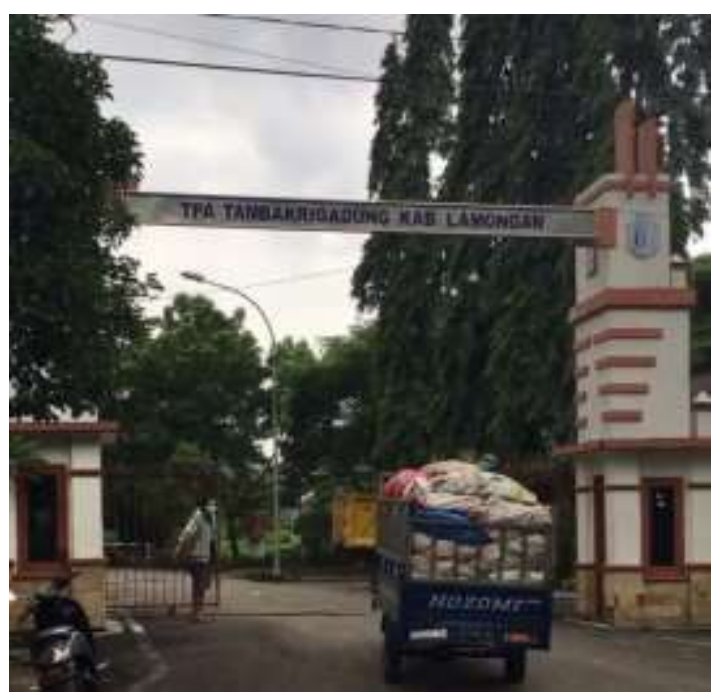

Gambar 3. TPA Tambakrigadung Kabupaten Lamongan

Sesuai dengan ijin yang telah diberikan Pemerintah Kabupaten Lamongan, maka pembuangan sampah ke TPA Tambakrigadung Lamongan tidak akan dikenakan biaya. Namun warga ditetapkan biaya sebesar Rp 10.000,00 sebagai pengganti biaya BBM dan honor petugas pengangkut sampah serta perawatan kendaraan pengangkut sampah. Memang dirasa bahwa biaya tersebut sangat sedikit, namun beberapa hal yang menjadi pertimbangan adalah pengelolaan ini tidak hanya sampai dengan pembuangan ke TPA namun nantinya berubah menjadi model desentralisasi dimana masyarakat akan dibina untuk meningkatkan cara pengelolaan sampah, mulai dengan memilah sampai nantinya mampu mendaur ulang sendiri sampah rumah tangganya.

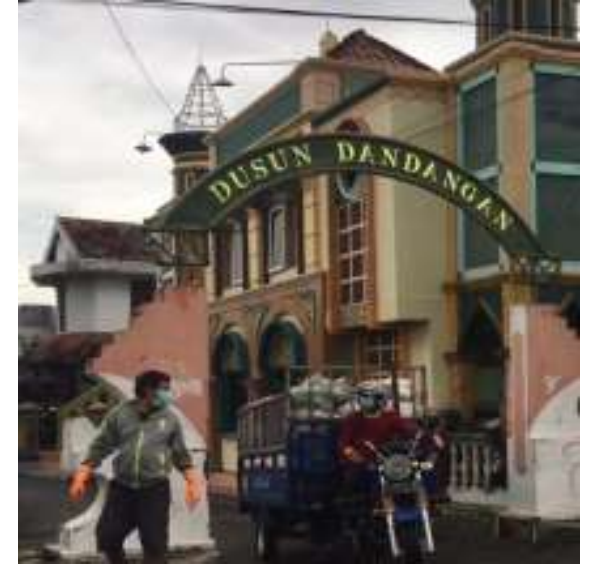

Gambar 4. Pengambilan Sampah dari Rumah Warga Dusun Dandangan

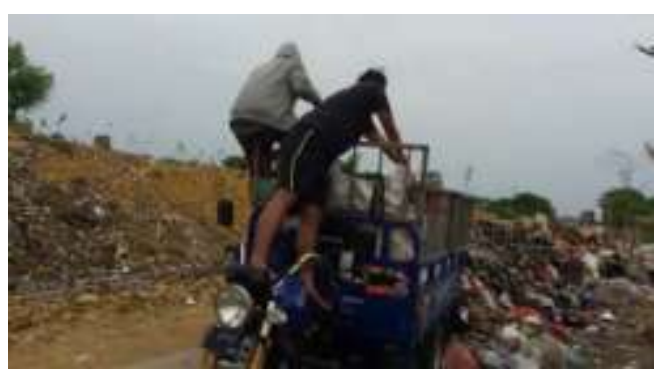

Gambar 5. Pembuangan ke TPA

Tambakrigadung Kabupaten Lamongan

\section{ULASAN KARYA}

Dengan model pengelolaan sampah seperti yang disebutkan pada subbab 3 memiliki kelebihan dibandingkan model desentralisasi yaitu cepat dikelola dan dibuang langsung ke TPA sehingga masalah dapat teratasi sementara waktu. Tapi bila diterapkan untuk jangka panjang maka terdapat kelemahan dari model pengelolaan ini, yaitu kebutuhan akan TPA yang luas untuk menampung sampah warga serta keberlanjutan petugas pengambil sampah ini, akankah selalu bertahan sampai lama. Karena bila dipikir lagi sampah yang akan dihasilkan oleh masyarakat tidak akan berkurang, tetapi akan bertambah seiring bertambahnya 
populasi manusia. Secara perhitungan dari $300 \mathrm{KK}$ atau 600 orang penduduk yang ada di Dusun Dandangan saat ini, setiap harinya menghasilkan $400 \mathrm{Kg}$ sampah. Sehingga dapat dihitung rata-rata volume sampah /orang / hari adalah sebanyak 0,667/liter/orang/hari[5]. Bila dalam dua tahun terjadi lonjakan jumlah penduduk $25 \%$ yaitu menjadi 750 orang penduduk maka setiap hari akan ada 500,25 Kg sampah yang harus diangkut per hari. Maka bagaimana cara mengangkut dan tenaga pengangkut yang diperlukan selanjutnya. Oleh karena itu sedikit demi sedikit mengubah cara pengelolaan sampah menjadi desentralisasi kemudian meningkat menjadi Se-Desentralisasi.

Dalam mewujudkan pengelolaan sampah secara Desentralisasi juga perlu perencanaan mengenai program pengurangan volume sampah oleh pihak produsen yaitu masyarakat Dusun Dandangan Kabupaten Lamongan. Perencanaan ini mengubah perilaku masyarakat yang mau mengolah sampah sebelum diangkut, sehingga kenaikan ratarata volume sampah tidak linier dengan kenaikan jumlah penduduk.

Pada model pengelolaan sentralisasi ini, sebelum diterapkan kepada masyarakat, terlebih dahulu dicari data mengenai pengetahuan masyarakat mengenai model pengelolaan sampah yang ada di Indonesia. Adapun pertanyaan yang diajukan untuk menggali data tingkat pengetahuan tentang pengelolaan sampah adalah sebagai berikut :

1. Sampah menjadi sumber penyakit bila dibiarkan saja tanpa diambil atau diolah;
2. Cara termudah dalam mengelola sampah adalah dikubur atau dibakar;

3. Pembakaran sampah mengakibatkan polusi udara dan menyumbang pemanasan udara di lingkungan kita;

4. Sampah dapat dibuang di sungai agar cepat hanyut ke laut dan permasalahan sampah terselesaikan;

5. Sampah plastik akan cepat terurai bila dikubur dalam tanah;

6. Pembusukan sampah menimbulkan bau busuk dan merusak kesehatan;

7. Cairan yang keluar dari sampah menyebabkan pencemaran air tanah, berakibat sumur akan tercemar;

8. Banjir tidak disebabkan oleh sampah yang ada di sungai melainkan adanya pendangkalan sungai;

9. Sampah yang menumpuk menjadi tempat bakteri dan virus yang mengancam kesehatan

10. Pengelolaan sampah merupakan tanggung jawab Pemerintah Daerah Kabupaten Lamongan.

Berdasarkan hasil kuesioner awal yang diberikan ke masing-masing warga, maka hasilnya adalah sebagai berikut :

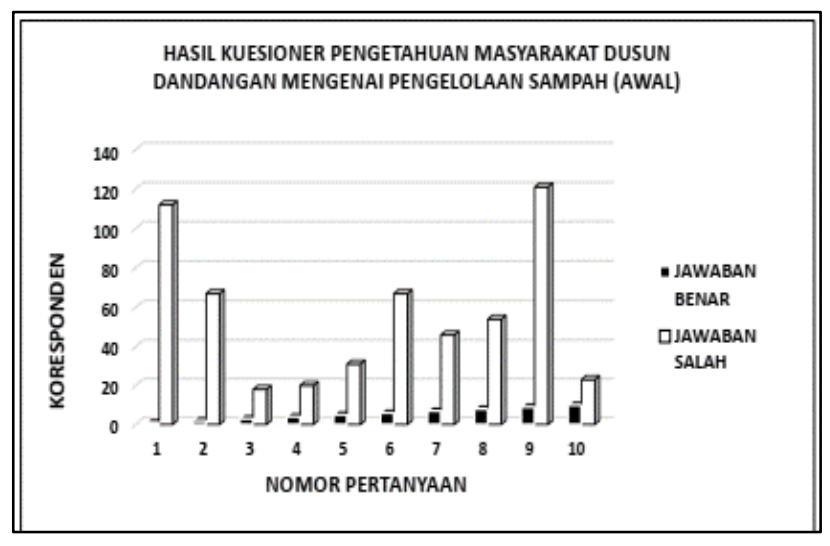

Gambar 6. Hasil Kuesioner Pengetahuan Masyarakat Dusun Dandangan Mengenai Pengelolaan Sampah (Awal) 
Dari Gambar 6 terlihat bahwa masyarakat Dusun Dandangan banyak yang tidak memiliki pengetahuan mengenai bagaimana mengelola sampah yang benar dan sesuai aturan pemerintah. Belum lagi masyarakat juga tidak mengetahui dampak akibat membuang atau mengolah sampah secara langsung di belakang rumah. Hal ini sangat memprihatinkan dan perlu penanganan serius agar kehidupan masyarakat lebih sehat, teratur dan nyaman. Sehingga tidak mengherankan bila warga Dusun Dandangan membuang sampahnya di belakang rumahnya yang notabene merusak lingkungan serta menyebabkan penyakit

Setelah dilakukan penyuluhan maka hasil kuesioner awal yang dibagikan berubah menjadi seperti berikut :

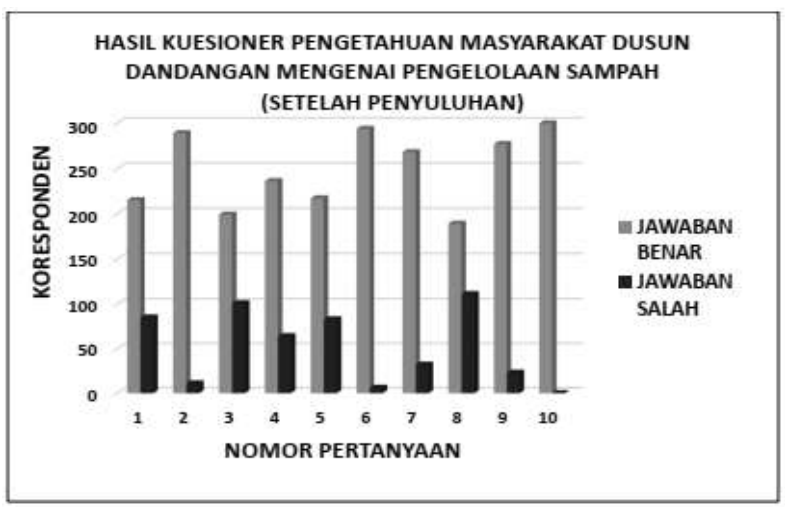

Gambar 7. Hasil Kuesioner Pengetahuan Masyarakat Dusun Dandangan Mengenai Pengelolaan Sampah (Setelah Penyuluhan)

Setelah dilakukan penyuluhan, pengetahuan baru mengenai pengelolaan sampah diterima oleh masyarakat, sekaligus bagaimana dampak yang akan ditimbulkan jika masih tetap menggunakan cara lama. Dalam penyuluhan juga mulai disampaikan bagaimanapun mengelola sampah sebelum menuju TPA lebih diharapkan karena semakin lama sampah tidak akan berkurang tetapi semakin banyak seiring pertambahan jumlah manusia/ masyarakatnya. Sehingga setelah warga memahami dampak pengelolaan sampah yang tidak benar, maka mulai menyadari bahwa menjaga kebersihan lingkungan sangat mutlak diperlukan. Tidak lagi langsung membuang sampah ke belakang rumah, namun dibungkus terlebih dahulu kemudian diletakkan di tong sampah depan rumah untuk menunggu pengambilan oleh petugas.

Oleh sebab itu pada tahap kedua setelah kegiatan ini, nanti akan dilanjutkan dengan pelatihan mendaur ulang sampah sampai bagaimana memproduksi sampah menjadi produk baru yang dapat digunakan kembali. Hal ini tidak hanya mempengaruhi ekosistem yang ada namun juga sosial budaya serta menambah income masyarakat bila produk yang dihasilkan memiliki value added.

\section{DAMPAK DAN MANFAAT KEGIATAN}

Dari kegiatan penyuluhan, banyak pengetahuan yang didapat masyarakat Dusun Dandangan, karena selama ini masih berpikir dengan pola lama yaitu mengelola sendiri sampahnya tanpa berpikir jangka panjang tentang efek polusi yang harus dihadapi, belum lagi pola hidup sehat tidak akan tercapai serta dampak secara sosial budaya masyarakat.

Manfaat kegiatan terlihat secara jelas dari hasil kuesioner kepuasan warga terhadap program pengelolaan sampah, apakah langsung mengena kepada kebutuhan masyarakat atau belum benarbenar mencapai harapan. Penghitungan kuesioner akan menggunakan skala Likert 
1 sampai dengan 5 yang bersifat positif. Berikut bobot nilai skala likert yang diberikan :

Tabel 1. Bobot Skala Likert

\begin{tabular}{lllcl}
\hline \multicolumn{4}{c}{ KRITERIA PENILAIAN } \\
\hline 1 & Tidak Puas & $=$ & $1-20$ & $\%$ \\
2 & Kurang Puas & $=$ & $21-40$ & $\%$ \\
3 & Netral & $=$ & $41-60$ & $\%$ \\
4 & Cukup Puas & $=$ & $61-80$ & $\%$ \\
5 & Puas Sekali & $=$ & $81-100$ & $\%$ \\
\hline
\end{tabular}

Pertanyaan yang diajukan terdiri dari :

1. Materi Program Pengelolaan Sampah sangat mudah dimengerti;

2. Tingkat kebersihan lingkungan Dusun Dandangan setelah Program dilaksanakan sangat meningkat dibanding sebelum ada kegiatan;

3. Motivasi yang diberikan penyuluh sangat membantu warga untuk lebih memperhatikan

kebersihan rumahnya;

4. Program ini mempererat kerjasama antara perangkat Dusun Dandangan, Karang Taruna ARDAS dan masyarakat Dusun Dandangan;

5. Penyuluh melakukan komunikasi yang baik dengan masyarakat dalam penyuluhan maupun pelaksanaan program;

6. Masyarakat diberikan kesempatan bertanya serta berdiskusi dengan pihak penyuluh apabila terdapat halhal yang tidak dimengerti;

7. Masyarakat bersedia bekerjasama dan bergotong royong untuk meningkatkan Program Pengelolaan Sampah ke tahap selanjutnya;

8. Masyarakat sangat bersedia untuk diberikan pelatihan pengolahan sampah menjadi program daur ulang;

9. Masyarakat ikut serta membantu Karang Taruna ARDAS untuk mengelola program berkelanjutan sampai tahap selanjutnya;

10. Masyarakat turut andil dalam menjaga kebersihan lingkungan rumahnya dengan mengelola sampahnya sesuai yang dianjurkan.

Dari pertanyaan-pertanyaan tersebut, maka ke-300 KK yang diberi kuesioner memberikan jawaban sebagai berikut :

Tabel 2. Penilaian Kuesioner

\begin{tabular}{|c|c|c|c|c|c|c|}
\hline $\begin{array}{c}\text { NO } \\
\text { KUESIONER }\end{array}$ & 1 & 2 & 3 & 4 & 5 & $\sum$ \\
\hline 1 & 0 & 0 & 12 & 16 & 272 & 1460 \\
\hline 2 & 0 & 0 & 0 & 3 & 297 & 1497 \\
\hline 3 & 0 & 0 & 25 & 42 & 233 & 1408 \\
\hline 4 & 0 & 0 & 0 & 84 & 216 & 1416 \\
\hline 5 & 0 & 0 & 10 & 31 & 259 & 1449 \\
\hline 6 & 0 & 0 & 0 & 77 & 220 & 1408 \\
\hline 7 & 0 & 0 & 8 & 9 & 283 & 1475 \\
\hline 8 & 0 & 0 & 13 & 38 & 249 & 1436 \\
\hline 9 & 0 & 0 & 0 & 34 & 266 & 1466 \\
\hline 10 & 0 & 0 & 44 & 61 & 195 & 1351 \\
\hline
\end{tabular}

Berdasarkan Tabel 2 dapat dihitung indeks penilaian responden dengan skor tertinggi skala likert yaitu :

Skor Tertinggi $\times$ jumlah responden

$$
=5 \times 300=1500
$$

Maka indeksnya adalah :

$$
\begin{aligned}
\text { Indeks }(\%)= & \frac{\text { Total Skor }}{Y} \times 100 \% \\
& =\frac{1436,6}{1500} \times 100 \% \\
& =95,77 \%
\end{aligned}
$$

Dari hasil tersebut maka program pengelolaan sampah ini Sangat

Memuaskan warga Dusun Dandangan Kabupaten Lamongan yang menginginkan wilayahnya bersih dan sehat serta berkeinginan berpartisipasi dalam tahap program selanjutnya.. 


\section{KESIMPULAN}

Program Pengelolaan Sampah yang dilaksanakan di Dusun Dandangan Kabupaten Lamongan sangat dibutuhkan seiring meningkatnya jumlah penduduk meningkat pula volume sampah yang dihasilkan masyarakat. Dari hasil kuesioner awal untuk mencari data mengenai pengetahuan masyarakat terhadap cara mengelola sampah, maka secara angka sangat mencengangkan dimana masyarakat tampak tidak peduli dan masih menggunakan cara-cara praktis dalam membuang sampah. Setelah program dilaksanakan, masyarakat merasakan dampak bersihnya lingkungan sekitar rumahnya dan semakin sadar bahwa sampah harus dikelola mulai dari rumah.

Kemudian dari kuesioner kedua tentang tingkat kepuasan masyarakat, maka diperoleh skor sebesar $95,77 \%$ yang berarti masyarakat merasa sangat puas atas Program Pengelolaan Sampah ini. Sehingga untuk ke depannya akan dilanjutkan dengan tahap kedua yaitu pelatihan pengelolaan sampah dari produsen sebelum menuju ke TPA.

\section{PENGHARGAAN}

Penghargaan penulis sampaikan kepada Kepala Dusun Dandangan Kabupaten Lamongan Bapak Sini'i karena sangat mendukung program pengelolaan sampah terpadu ini dengan visi mewujudkan daerah Dusun Dandangan yang bersih dan sehat, sehingga penulis sangat berterimakasih kegiatan dapat berlangsung lancar dan berhasil bagi warga Dusun Dandangan.

\section{DAFTAR PUSTAKA}

[1] kompasmuda.com. "Sampah Jakarta 7500 ton per hari". 22 Januari 2016. $<$ http://

kompasmudahttp://www.hoovers/.com /2016/01/22/sampah-jakarta-7500-tonper-hari/ diakses pada tanggal 8 April 2019.

[2] Undang-Undang Republik Indonesia Nomor 18 Tahun 2008 tentang Pengelolaan Sampah

[3] sanitasidisini.wordpress.com. "Undangundang melarang TPA open dumping, bagaimana prakteknya?" 13 Mei 2011. < https://sanitasidisini.wordpress.com/20 11/05/13/undang-undang-melarangtpa-open-dumping-bagaimanaprakteknya/> diakses pada tanggal 10 April 2019.

[4] H. Asrul Hoesein. "Pengelolaan Sampah Terpadu Berbasis Masyarakat" 27 November 2010.

<https://www.kompasiana.com/hasrul hoesein/550049f08133112819fa7578/ pengelolaan-sampah-terpadu-berbasis$\underline{\text { masyarakat }>\text { diakses pada tanggal } 10}$ April 2019

[5] Herman Herbandi. "Menghitung Timbunan Sampah Kota” 13 Desember 2016. < http://tulisanhherbandi.blogspot.com/2016/12/men ghitung-populasi-dan$\underline{\text { sampelunit.html }>\text { diakses pada tanggal }}$ 12 April 2019. 